\title{
STUDY OF GOOD CORPORATE GOVERNANCE IMPLEMENTATION IN LISTED STATE-OWNED ENTERPRISES THROUGH A CONTENT ANALYSIS METHOD OF ANNUAL REPORTS
}

\author{
Sally Marcelina Djauhari ${ }^{1}$ \\ Bank Commonwealth \\ Parulian Sihotang ${ }^{2}$ \\ BP MIGAS
}

\begin{abstract}
Good Corporate Governance (GCG) is a concept of directing and controlling business corporations. This concept specifies the distribution of rights and obligations between the company's stakeholders and the procedures for taking decisions on corporate affairs. It provides a mechanism through which the company's objectives are set, and for attaining those objectives and monitoring performance.

The main objective of this study is to explore how far the GCG principles have been implemented in listed State-Owned Enterprises (SOE). In addition, the writer compares the GCG implementation among the participant companies as well as across the industries, in which the companies are classified.

The method used in the data collection is observation through the company's annual report (content analysis). The writer uses GCG Evaluation Manual of Badan Pengawasan Keuangan dan Pembangunan (BPKP) released and endorsed in 2004 by the Ministry of SOE, as the scoring system.

The results generated from this study are the company's scores in implementing the GCG principles. In addition, the writer generates ranking among the participant companies, within the same industry and across the industries.
\end{abstract}

\footnotetext{
${ }^{1}$ Staff Bank Commonwealth (astrie.dewi@commbank.co.id)

2 Senior Manager BP MIGAS (psihotang@bpmigas.go.id)
} 
The best company with the highest score in implementing the GCG principles among the participant companies is Aneka Tambang. In addition, the top companies with the highest scores within each industry are Bank BNI (Finance), Indofarma (Consumption Goods), Telkom (Infrastructure, Utility \& Transportation), and Aneka Tambang (Mining). Moreover, the best industry with the highest average score of the players is Property \& Real Estate.

Keywords: good corporate governance, assessment, Indonesian stateowned enterprise

\section{INTRODUCTION}

There are two important issues that realized the Indonesian government of how important Good Corporate Governance (GCG) concept is for building a strong economic condition. The first one is the great East Asian financial crisis that attacked Indonesia in 1997. According to a study conducted by World Bank, a major factor of the crisis was the inconsistency of GCG implementation (Patriadi 2004). At that time, the economy of Indonesia was suffering from poor quality of investment, excessive diversification in areas that totally unrelated to the core business (including diversification into unproductive or overly-priced real estate), and great exposure to debt, especially unhedged short-term foreign debt (Asia After the Crisis: An Age of Governance). As the result, property assets collapsed and many foreign capital exit. As a way out of crisis, Indonesian government signed a Letter of Intent (LOI) with IMF, in which one of the important parts is about a schedule of corporate governance improvement in Indonesia (Suprayitno et al. 2006).

The second issue is massive accounting scandals that happened in Indonesia following the crisis. The first scandal is the case of Lippo Bank, which was a private bank with 2.5 million customers (GCG Overview). In 1997, the company's management reported a net profit of 98 million IDR instead of a net loss of 1.3 trillion IDR (GCG Overview). The second case is the case of Kimia Farma, which was a state-owned enterprise (SOE) in

pharmacy industry. In 2001, the company’s management blew up the net 
profit for 32.6 million IDR. They reported 132 million IDR instead of 99.6 million IDR (GCG Overview).

For those main reasons, Indonesian government started to develop and implement the GCG in Indonesia. In 1999, the government formed an institution called Komite Nasional Kebijakan Governance (KNKG). This Committee is responsible to arrange and develop some recommendations for national corporate governance policy, such as a Code for Good Corporate Governance. In addition, the Ministry of State OwnedEnterprise (SOE) through Surat Keputusan Menteri BUMN no Kep$117 / M-M B U / 2002$ obliged all the SOE to implement GCG in order to increase the company value and encourage the professional, transparent and efficient, accountable, fair, reliable and responsible governance of the company.

Moreover, private sector also contributes significantly in the development and socialization of GCG. There are many independent institutions intended to socialize the GCG in Indonesia, such as Forum for Corporate Governance in Indonesia (FCGI), Lembaga Komisaris dan Direktur Indonesia (LKDI), Ikatan Komite Audit Indonesia (IKAI), Indonesian Institute for Corporate Directorship (IICD), Indonesian Society of Independent Commissioners (ISICOM), KADIN Indonesia Komite Tetap GCG and Indonesian Institute for Corporate Governance (IICG) (Suprayitno et al. 2006).

Now, after much effort has been exercised, how far has the concept of GCG been implemented? This research is designed to answer the following questions: (1) Have all listed SOE implemented the GCG? (2) To what extent have those companies implemented the GCG in regards to GCG Evaluation Manual of BPKP? (3) How is the GCG implementation ranking among the SOE? (4) How is the GCG implementation ranking within and among the industries, in which the SOE are classified in?

\section{LITERATURE REVIEW}

A definition released by Organization for Economic Cooperation and Development (OECD) in April 1999 for corporate governance is as the following. 
'Corporate governance is the system by which business corporations are directed and controlled. The corporate governance structure specifies the distribution of rights and responsibilities among different participants in the corporation, such as, the board, managers, shareholders and other stakeholders, and spells out the rules and procedures for making decisions on corporate affairs. By doing this, it also provides the structure through which the company objectives are set, and the means of attaining those objectives and monitoring performance.' (OECD, cited in Pieris \& Wiryawan 2007, p.141)

According to Indonesian GCG Code 2006, there are five general principles that need to be implemented in order to achieve a company's sustainability (National Committee on Governance 2006).

1. Transparency

To apply transparency principle, a company must disclose material and relevant information that is easily accessible and understandable by stakeholders.

2. Accountability

To apply accountability principle, a company must be managed properly, and its performance should be measured accurately.

3. Responsibility

To be responsible means that a company is abide by laws and regulations, and also fulfill its responsibility to the communities and environment where it exists.

4. Independency

To apply independency principle, a company must be managed in such a way that there is neither a domination of a single party nor intervention from other party shall exist.

5. Fairness

To apply fairness principle, a company must consider the interests of its different stakeholders in performing its activities.

\section{DATA AND RESEARCH METHODOLOGY}

The scope of this study is to assess the implementation of GCG in the SOE which have been listed during and before the year of 2004. Therefore, there are thirteen listed SOE that will be assessed, which are PT. Adhi 
Karya Tbk, PT. Aneka Tambang Tbk, PT. Bank Mandiri Tbk, PT. Bank Negara Indonesia Tbk, PT. Bank Rakyat Indonesia Tbk, PT. Indofarma Tbk, PT. Indosat Tbk, PT. Kimia Farma Tbk, PT. Perusahaan Gas Negara Tbk, PT. Semen Gresik Tbk, PT. Tambang Batu Bara Bukit Asam Tbk, PT. Telekomunikasi Indonesia Tbk, and PT. Timah Tbk.

The thirteen listed SOE can be divided into five industries based on their major business area, which are:

- Consumption Goods (Indofarma, Kimia Farma)

- Finance (Bank BNI, Bank BRI, Bank Mandiri)

- Infrastructure, Utility \& Transportation (Indosat, Telkom)

- Mining (Aneka Tambang, Perusahaan Gas Negara, Perusahaan Tambang Batu Bara, Semen Gresik, PT Timah)

- $\quad$ Property \& Real Estate (Adhi Karya)

This study is an exploratory study, in which the immediate objective is to have a preliminary assessment of GCG implementation in listed SOE. The methodology used is a content analysis performed through observation of the companies' annual reports for the period of 2004 to 2006 using quantitative technique. Under this study, the implementation of GCG in the thirteen listed SOE is assessed using a scoring system called GCG Evaluation Manual of Badan Pengawasan Keuangan dan Pembangunan (BPKP). The GCG Evaluation Manual of BPKP is developed by Corporate Governance Team of BPKP and endorsed by the Ministry of State-Owned Enterprise in 2004. The Manual consists of many criteria that divided into four components, which are Shareholders' Rights, Corporate Governance Policy (CG Policy), Corporate Governance Practices (CG Practices), and Disclosure \& Transparency. Due to the research methodology used is content analysis; when there is any inapplicable criterion in the Manual to be answered; those criteria will be excluded to keep the score result free from bias.

\section{FINDINGS AND DISCUSSION}

Based on the research and assessment process through the observation of each company's annual report, which cover the year 2004 to 2006, it can be measured that the implementation of GCG concept in the thirteen listed SOE are as the following. It should be noticed that due to this research 
process is exploratory in nature; the following findings are still tentative that could be the object of further research.

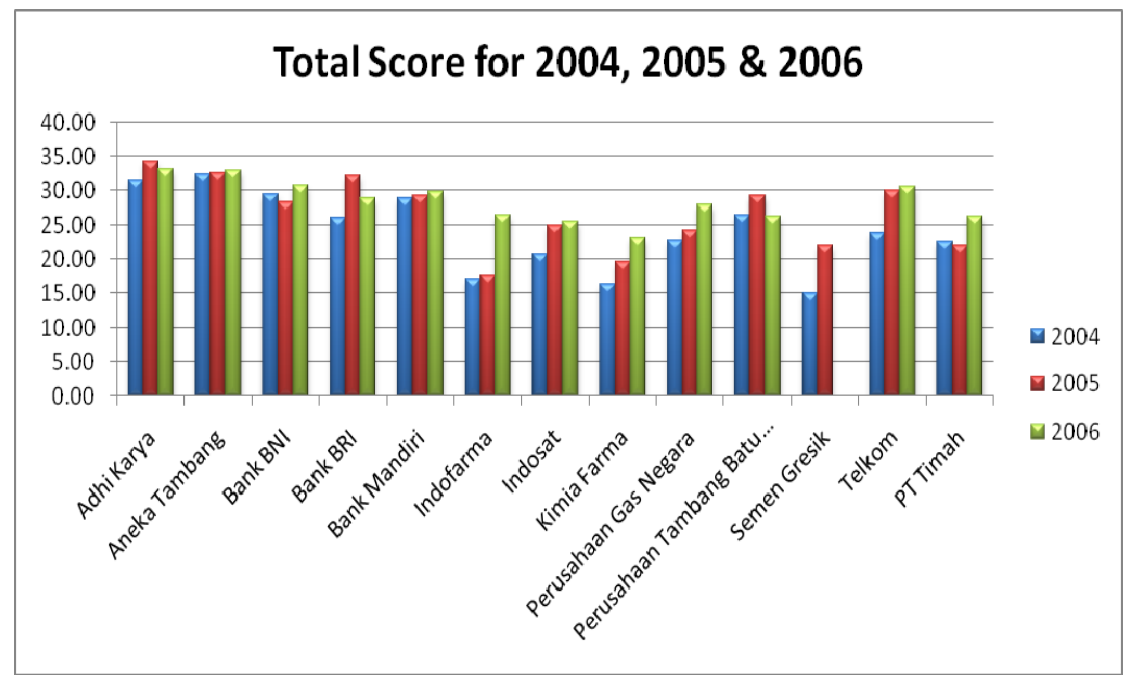

Figure 1. Total Score for 2004-2006

From the diagram above, it can be seen that all of the listed SOE have implemented the GCG principles. The average rating score of 25.63 out of 44.75 (57 percent) covering the period of three years. Based on the average score for three years, there are three companies with the highest scores, which are Aneka Tambang (77.18 percent), Adhi Karya (77.14 percent), and Bank BNI (69.48 percent). On the other hand, there are three companies with the lowest scores, which are Semen Gresik (43.31 percent), Kimia Farma (46.51 percent) and Indofarma (47.07 percent). The rating score for each company per year is the total score of four components assessed in the rating process. The four components consist of Shareholders' Right, Corporate Governance Policy, Corporate Governance Practices, and Disclosure and Transparency. Each of the component will be described as the following, along with the average score per company for each component.

The Shareholders' Right component assesses the corporate governance system which is implemented by a company in order to protect and facilitate the execution of shareholders' right. The average score for this component is 1.37 out of 3.75 (37 percent); which is still far away from 
the best practices in fulfilling its shareholders' right. The three companies with the highest scores (in percentage of the best practices score) for this component are Bank Mandiri (60 percent), Bank BNI (51 percent) and Bank BRI (49 percent). On the other hand, there are five companies with the lowest scores, which are Indofarma (9 percent), Perusahaan Gas Negara (24 percent), Indosat (27 percent), Telkom (27 percent) and Semen Gresik (27 percent).

The Corporate Governance Policy component assesses the commitment of a company's organs to run the company based on the GCG principles. The real action of the commitment can be seen from whether a company has developed its Board Manual, in which the obligations of BoC and BoD, the rights of shareholders, policies and accomplishments expected from Board, the Board's meeting process are set clearly. The average score for this component is 2.22 out of 5.5 (40 percent). The three companies with the highest scores (in percentage of the best practices score) for this component are Aneka Tambang (86 percent), Telkom (56 percent) and Bank BNI (49 percent). On the other hand, the three companies with the lowest scores are PT Timah (15 percent), Indofarma (21 percent) and Semen Gresik (23 percent).

The Corporate Governance Practices component assesses corporate governance system which assures the accomplishment of $\mathrm{BoC}$ and $\mathrm{BoD}$ responsibilities in governing a company. The average score for this component is 16.46 out of 29 (57 percent); which is above the average as their scores are more than 50 percent of the best practices. The three companies with the highest scores (in percentage of the best practices score) for this component are Adhi Karya (80 percent), Aneka Tambang (69 percent) and Bank Mandiri (67 percent). On the other hand, the three companies with the lowest scores are Kimia Farma (34 percent), Semen Gresik (39 percent) and Indofarma (43 percent).

Disclosure and Transparency component assesses the corporate governance system that assures the completeness and accuracy of the disclosure regarding the relevant and material information through various media. The average score for Disclosure and Transparency component is 6.06 out of 6.5 (93 percent). The four companies with the perfect score (100 percent - in percentage of the best practices score) for this 
component, which are Aneka Tambang, Bank BNI, Telkom, and PT Timah. On the other hand, the three companies with the lowest scores are Semen Gresik (77 percent), Kimia Farma (83 percent) and Bank Mandiri (87 percent).

In the area of any improvement a company made during the period of three years, there are three companies with the highest increasing rate, which are Indofarma (27.18 percent), Kimia Farma (18.97 percent), and Telkom (13.99 percent). On the other hand, there are three companies with the lowest increasing rate, which are Perusahaan Tambang Batu Bara (0.10 percent), Aneka Tambang (0.77 percent) and Bank Mandiri (1.72 percent).

The leading companies in implementing the GCG principles within each industry are Bank BNI (69.5 percent) in the Finance industry, Indofarma (47.1 percent) in the Consumption Goods industry, Telkom (66 percent) in Infrastructure, Utility \& Transportation industry, and Aneka Tambang (77.2 percent) in Mining industry. There is no leading company in the Property \& Real Estate industry, as it only consists of one player.

The following figure presents the average score from 2004 to 2006 for each component across the industries.

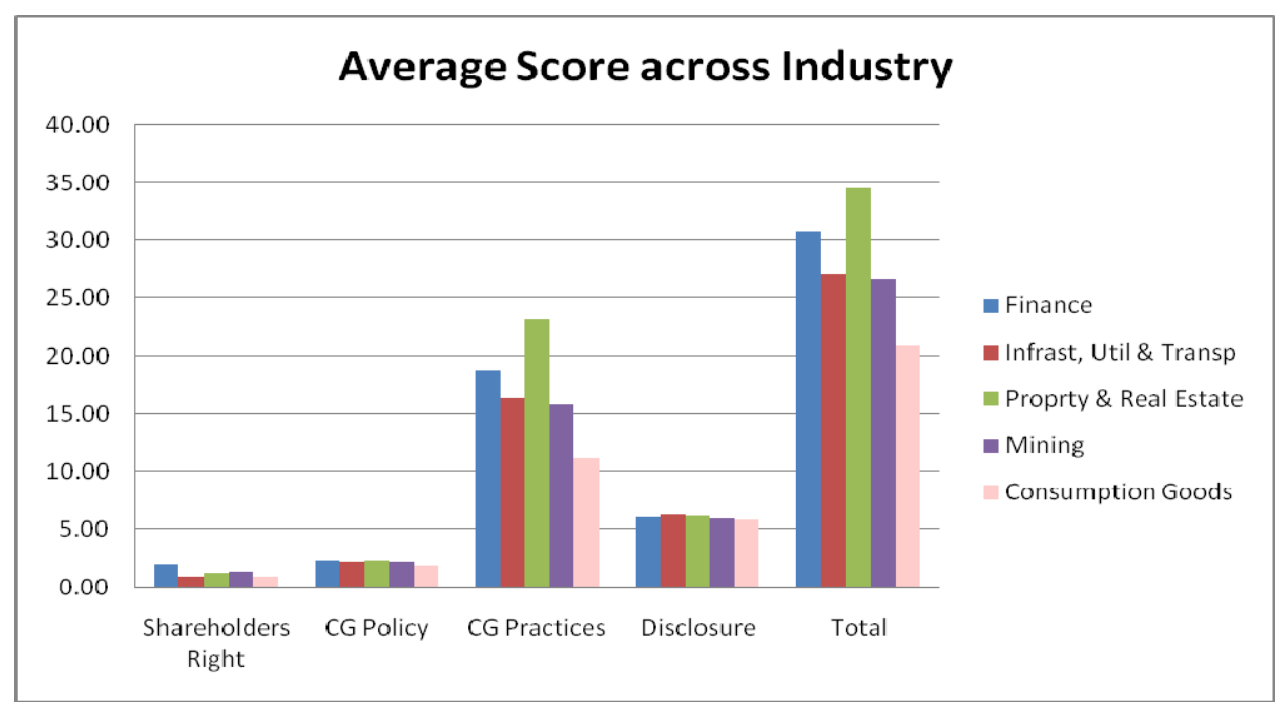

Figure 2. Average Score across Industry 
From the above figure, it can be seen that across the five industries, Property \& Real Estate industry got the highest total score (77.1 percent), followed by Finance (68.9 percent), Infrastructure, Utility \& Transportation (60.7 percent), Mining (59.6 percent), and Consumption Goods (46.8 percent). From each component, it can be seen that Property \& Real Estate industry got the highest scores for CG Policy (43.2 percent) and CG Practices (79.9 percent). Being in the second position, Finance industry got the highest score for Shareholders' Right component (53.3 percent). On the other hand, Infrastructure, Utility \& Transportation industry which comes on the third place, got the highest score for Disclosure \& Transparency component (97.4 percent).

In the area of any improvement made during the period of three years, Consumtion Goods is in the first place with 17.8 percent improvement, followed by Infratructure, Utility \& Transportation (12.7 percent), Mining (9 percent), Finance (3.1 percent) and Property \& Real Estate (2.7 percent).

\section{CONCLUSION AND RECOMMENDATION}

Based on the findings and discussion, it can be concluded that all the thirteen listed SOE have implemented the GCG principles. However, the implementation levels are different among the companies in regards to the GCG Evaluation Manual of BPKP released and endorsed in 2004 by the Ministry of SOE. The best company in implementing the GCG principles is Aneka Tambang, while the best industry is Property \& Real Estate.

Based on each component of the Manual scoring system, it can be concluded as the following.

- Bank Mandiri, Bank BNI and Bank BRI as well as Finance industry treat their shareholders' right best among the companies/ industries participant.

- Aneka Tambang, Telkom and Bank BNI are the most committed companies in implementing the GCG principles, by providing the necessary policies needed to conduct the GCG practices, whereas the most committed industry is Property \& Real Estate. 
- Adhi Karya, Aneka Tambang and Bank Mandiri as well as Property \& Real Estate industry have implemented better company structures compare to the other companies/industries, which assure that the governing process of the company is well functioned.

- Aneka Tambang, Bank BNI, Telkom and PT Timah are the most transparent among the thirteen companies, while the most transparent industry is Infrastructure, Utility \& Transportation.

In the area of any improvement made in implementing the GCG principles during the year 2004 to 2006, the greatest improvement was showed by Indofarma as well as Consumption Goods industry.

The leading companies in implementing the GCG principles within each industry are Bank BNI (Finance industry), Indofarma (Consumption Goods industry), Telkom (Infrastructure, Utility \& Transportation industry), and Aneka Tambang (Mining industry). There is no leading company in the Property \& Real Eastate industry, as it only consists of one player.

An important recommendation proposed by the writer in order to improve the implementation of GCG principles in listed companies, especially in listed SOE is to obligate all listed companies to participate in such assessment and rating process held by independent institutions, such as Indonesian Institute for Corporate Governance (IICG), etc

The writer admits that there are many limitations in this study. The main limitation is the research process under this study is exploratory in nature; therefore the findings are still tentative. For generalization of the findings, further quantitative research is needed. In addition, the data used in this study is only collected through the observation of the company's annual report. There is no confirmation or interview conducted with the company's management. Moreover, the writer could not access most of the company's Board Manual and Code of Conduct/Ethics as only two companies have published it over the internet. Furthermore, as the research methodology used is content analysis, there are some inapplicable criteria of the Manual scoring system that can not be answered. Therefore, those criteria are left unanswered to keep the score result free from bias. 
Therefore, the writer proposes some recommendations that may be useful in conducting any further research, which are.

o Conduct an interview with the company's management in order to assess the real practices regarding the GCG implementation

o Ask a permission to have a look at the company's Board Manual and Code of Conduct/Ethics as only a few companies have published it over the internet

o Expand the scope of participants that will be assessed in order to have sufficient data in comparing the players within the industry

o Expand the period of annual report that will be assessed in order to have sufficient data in analysing the trend of the GCG implementation within a company or an industry

\section{REFERENCES}

Asia After the Crisis: An Age of Governance. Managing Corporate Governance in Asia Newsletter, June 2001. Retrieved February 25, 2008, from http://www.rvr.aim.edu.ph/mcga/reads/crisis.htm

GCG Overview, Retrieved February 25, 2008, from http://www.pusri.co.id/data/gcg/GCG_Overview2007.pdf

Keputusan Ketua Badan Pengawas Pasar Modal no Kep-38/PM/1996 Tentang Laporan Tahunan 1996 (Ketua Badan Pengawas Pasar Modal)

Keputusan Menteri Badan Usaha Milik Negara no Kep 117/M-MBU/2002 Tentang Penerapan Praktek Good Corporate Governance pada Badan Usaha Milik Negara (BUMN) 2002 (Menteri Badan Usaha Milik Negara)

National Committee on Governance 2006, Indonesia's Code of Good Corporate Governance, media release, National Committee on Governance, Jakarta, 17 October. Retrieved February 10, 2008, from http://www.acgaasia.org/public/files/Indonesia\%20Code\%20of\%20GCG\%202006. pdf 
Patriadi, P. (2004). Manfaat Konsep Good Governance bagi Institusi Pemerintah dan BUMN dalam Kebijakan Privatisasi BUMN, Kajian Ekonomi dan Keuangan, vol. 8, no. 3. Retrieved February 8, 2008, from http://muhariefeffendi.files.wordpress.com/2007/11/pandu-3-gcgdepkeu.pdf

Pieris, J. \& Wiryawan, N.J. (2007). Etika Bisnis dan Good Corporate Governance. Jakarta: Penerbit Pelangi Cendekia.

Suprayitno, G, Khomsiyah, Darmawati, D, Yasni, Susandy, M \& Ratnawati (2006). Laporan Corporate Governance Perception Index 2005, Retrieved March 2, 2008, from http://www.iicg.org/laporan\%20cgpi\%202005.pdf 